\title{
Sediment management modelling in the Blue Nile Basin using SWAT model
}

\author{
G. D. Betrie ${ }^{1,2}$, Y. A. Mohamed ${ }^{1,2,3}$, A. van Griensven ${ }^{1}$, and R. Srinivasan ${ }^{4}$ \\ ${ }^{1}$ UNESCO-IHE Institute for Water Education, P.O. Box 3015, 2601DA Delft, The Netherlands \\ ${ }^{2}$ Delft University of Technology, P.O. Box 5048, 2600 GA Delft, The Netherlands \\ ${ }^{3}$ Hydraulic Research Station, Wad Medani, Sudan \\ ${ }^{4}$ Texas A\&M University, College Station, Texas, USA
}

Received: 10 July 2010 - Published in Hydrol. Earth Syst. Sci. Discuss.: 11 August 2010

Revised: 17 February 2011 - Accepted: 19 February 2011 - Published: 8 March 2011

\begin{abstract}
Soil erosion/sedimentation is an immense problem that has threatened water resources development in the Nile river basin, particularly in the Eastern Nile (Ethiopia, Sudan and Egypt). An insight into soil erosion/sedimentation mechanisms and mitigation methods plays an imperative role for the sustainable water resources development in the region. This paper presents daily sediment yield simulations in the Upper Blue Nile under different Best Management Practice (BMP) scenarios. Scenarios applied in this paper are (i) maintaining existing conditions, (ii) introducing filter strips, (iii) applying stone bunds (parallel terraces), and (iv) reforestation. The Soil and Water Assessment Tool (SWAT) was used to model soil erosion, identify soil erosion prone areas and assess the impact of BMPs on sediment reduction. For the existing conditions scenario, the model results showed a satisfactory agreement between daily observed and simulated sediment concentrations as indicated by Nash-Sutcliffe efficiency greater than 0.83 . The simulation results showed that applying filter strips, stone bunds and reforestation scenarios reduced the current sediment yields both at the subbasins and the basin outlets. However, a precise interpretation of the quantitative results may not be appropriate because some physical processes are not well represented in the SWAT model.
\end{abstract}

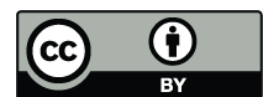

Correspondence to: G. D. Betrie (g.betrie@unesco-ihe.org)

\section{Introduction}

The Blue Nile River, which originates from the steep mountains of the Ethiopian Plateau, is the major source of sediment loads in the Nile basin. Soil erosion from the upstream of the basin and the subsequent sedimentation in the downstream area is an immense problem threatening the existing and future water resources development in the Nile basin. The benefits gained by the construction of micro-dams in the Upper Nile are threatened by the rapid loss of storage volume due to excessive sedimentation (El-Swaify and Hurni, 1996; Tamene et al., 2006). Moreover, the green water storage of the Ethiopian highlands, where rainfed agriculture prevails is diminished because of top-soil loss and this has caused frequent agricultural drought (Hurni, 1993; El-Swaify and Hurni, 1996). In the downstream part of the basin (e.g., in Sudan and Egypt) excessive sediment load led to massive operation cost of irrigation canals desilting, and sediment dredging in front of hydropower turbines. For example, the Sinnar dam has lost $65 \%$ of its original storage after 62 years operation (Shahin, 1993) and the other dams (e.g., Rosieres and Khashm el Girba) lost similar proportions since construction (Ahmed, 2004). Both the Nile Basin Initiative and the Ethiopian government are developing ambitious plans of water resources projects in the Upper Blue Nile basin, locally called the Abbay basin (BCEOM, 1999; World Bank, 2006). Thus, an insight into the soil erosion/sedimentation mechanisms and the mitigation measures plays an indispensable role for the sustainable water resources development in the region.

Literature review shows there are many catchment models that include the soil erosion/sedimentation processes and simulate the effect of mitigation measures (Merritt et al.,

Published by Copernicus Publications on behalf of the European Geosciences Union. 


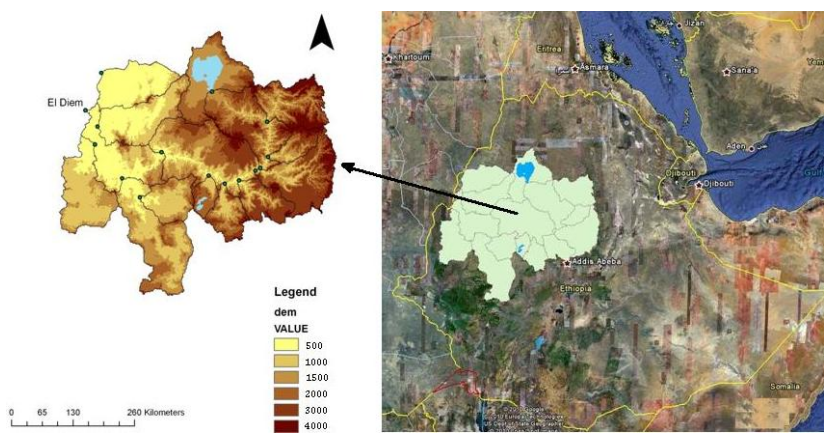

Fig. 1. Location map of the Upper Blue Nile.

2003; Borah and Bera, 2003). However, there are a few applications of erosion modelling in the Upper Blue Nile basin. These include Zeleke (2000), Haregeweyn and Yohannes (2003), Mohamed et al. (2004), Hengsdijk et al. (2005), Steenhuis et al. (2009), and Setegn et al. (2010). Zeleke (2000) simulated soil loss using the Water Erosion Prediction Project (WEPP) model and the result slightly underestimated the observed soil loss in the Dembecha catchment (27 100 ha). Haregeweyn and Yohannes (2003) applied the Agricultural Non-Point Source (AGNPS) model and well predicted sediment yield in the Augucho catchment (224 ha). The same AGNPS model was used by Mohamed et al. (2004) to simulate sediment yield in the Kori (108 ha) catchment and the result was satisfactory. Hengsdijk et al. (2005) applied the Limburg Soil Erosion Model (LISEM) to simulate the effect of reforestation on soil erosion in the Kushet - Gobo Deguat catchment (369 ha), but the result raised controversy by Nyssen et al. (2005). The SWAT model was applied for simulation of a sediment yield by Setegn et al. (2010) in the Anjeni gauged catchment (110 ha) and the obtained result was quite acceptable. Steenhuis et al. (2009) calibrated and validated a simple soil erosion model in the Abbay (Upper Blue Nile) basin and reasonable agreement was obtained between the model predictions and the 10-day observed sediment concentration at El Diem located at the Ethiopia-Sudan border.

The application of models to simulate effectiveness of soil and water conservation practices in the Ethiopian highlands is less explored compared to the application of models to estimate soil losses. However, there are a few publications on the observed effects of soil and water conservation practices at a plot and at field scales (Herweg and Ludi, 1999; Descheemaeker et al., 2006; Gebremichael et al., 2005). Herweg and Ludi (1999) investigated the performance of selected soil and water measures at a plot scale and the results showed that a significant reduction in soil loss and runoff. Descheemaeker et al. (2006) reported a high capacity of sediment trapping at a field scale due to reforestation measures. Gebremichael et al. (2005) showed that a considerable sediment reductions by stone bunds at a field scale.
Most of the above modelling applications successfully attempted to estimate the sediment yield at a small catchment scale or evaluate their soil erosion model. However, there is no literature that shows models prediction on the effects of mitigation measures at a large scale in the Blue Nile. Therefore, the objective of this study is to model the spatially distributed soil erosion/sedimentation process in the Upper Blue Nile basin at a daily time step and assess the impact of different catchment management interventions on sediment yield.

A brief description of the Upper Blue Nile Basin is given in the next section, followed by a discussion of the methodology used. The third section presents the model results and discussion of different land management scenarios. Finally, the conclusion summarizes the main findings of the investigations.

\section{Description of study area}

The Upper Blue Nile River basin has a total area of 184, $560 \mathrm{~km}^{2}$, and is shown in Fig. 1. The Ethiopian Plateau is deeply incised by the Blue Nile River and its tributaries, with a general slope to the north-west. The elevation ranges from $500 \mathrm{~m}$ at Sudan border to $4230 \mathrm{~m}$ at the top of highlands. The Didessa and Dabus tributaries drain the south-western part of the basin, and contribute about one third of the total flow. The climate in the Blue Nile is governed by the seasonal migration of the Inter Tropical Convergence Zone ITCZ from the south to the north and back. The annual rainfall varies from $900 \mathrm{~mm}$ near the Ethiopia/Sudan border to $2200 \mathrm{~mm}$ in the Didessa and the Dabus subbasins. Since the rainfall is highly seasonal, the Blue Nile possesses a highly seasonal flood regime with over $80 \%$ of annual discharge occurs from July to October, while $4 \%$ of the flow occurs between January and April (Sutcliffe and Parks, 1999). In the basin the minimum and the maximum temperatures are $11^{\circ} \mathrm{C}$ and $18^{\circ} \mathrm{C}$, respectively. The dominant soil types are Alisols and Leptosols $21 \%$, followed by Nitosoils $16 \%$, Vertisols $15 \%$ and Cambisols $9 \%$.

\section{Methodology}

\subsection{SWAT model description}

The Soil and Water Assessment Tool (SWAT) is a physical process based model to simulate continuous-time landscape processes at a catchment scale (Arnold et al., 1998; Neitsch et al., 2005). The catchment is divided into hydrological response units (HRUs) based on soil type, land use and slope classes that allows a high level of spatial detail simulation. The major model components include hydrology, weather, soil erosion, nutrients, soil temperature, crop growth, pesticides agricultural management and stream routing.

The model predicts the hydrology at each HRU using the water balance equation, which includes daily precipitation, 
Table 1. Spatial model input data for the Upper Blue Nile.

\begin{tabular}{llll}
\hline Data type & Description & Resolution & Source \\
\hline Topography map & Digital Elevation Map (DEM) & $90 \mathrm{~m}$ & SRTM \\
Land use map & Land use classifications & $1 \mathrm{~km}$ & GLCC \\
Soils map & Soil types & $10 \mathrm{~km}$ & FAO \\
Weather & $\begin{array}{l}\text { Daily precipitation and } \\
\text { minimum and maximum temperature }\end{array}$ & 17 stations & $\begin{array}{l}\text { Ethiopian Ministry } \\
\text { of Water Resources }\end{array}$ \\
\hline
\end{tabular}

Table 2. Land use/Land cover types and area coverage in the Upper Blue Nile.

\begin{tabular}{llr}
\hline Landuse & Description & Area $(\%)$ \\
\hline Dryland Cropland & Land used for agriculture crop & 17 \\
Cropland & Land area covered with mixture of croplands, shrublands, and grasslands & 5.8 \\
Grassland & Land covered by naturally occurring grass & 2.5 \\
Shrubland & Lands characterized by xerophytic vegetative types & 1.1 \\
Savanna & Lands with herbaceous and other understory systems height exceeds 2 m height & 68.8 \\
Deciduous Broadleaf Forest & Land dominated by deciduous broadleaf trees & 0.02 \\
Evergreen Broadleaf Forest & Land dominated by evergreen broadleaf trees & 1.6 \\
Mixed Forest & Land covered by both deciduous and evergreen trees & 0.7 \\
Water Body & Area within the landmass covered by water & 2.2 \\
Barren & Land with exposed rocks and limited ability to support life & 0.4 \\
Residential Medium Density & Land area covered by structures such as town & 0.2 \\
\hline
\end{tabular}

runoff, evapotranspiration, percolation and return flow components. The surface runoff is estimated in the model using two options (i) the Natural Resources Conservation Service Curve Number (CN) method (USDA-SCS, 1972) and (ii) the Green and Ampt method (Green and Ampt, 1911). The percolation through each soil layer is predicted using storage routing techniques combined with crack-flow model (Arnold et al., 1995). The evapotranspiration is estimated in SWAT using three options (i) Priestley-Taylor (Priestley and Taylor, 1972), (ii) Penman-Monteith (Monteith, 1965) and (iii) Hargreaves (Hargreaves and Riley, 1985). The flow routing in the river channels is computed using the variable storage coefficient method (Williams, 1969), or Muskingum method (Chow, 1959).

The SWAT model uses the Modified Universal Soil Loss Equations (MUSLE) to compute HRU-level soil erosion. It uses runoff energy to detach and transport sediment (Williams and Berndt, 1977). The sediment routing in the channel (Arnold et al., 1995) consists of channel degradation using stream power (Williams, 1980) and deposition in channel using fall velocity. Channel degradation is adjusted using USLE soil erodibility and channel cover factors.

\subsection{SWAT model setup}

The SWAT model inputs are Digital Elevation Model (DEM), landuse map, soil map, and weather data, which is shown in
Table 1. The ArcGIS interface (Winchell et al., 2007) of the SWAT2005 version was used to discretize a watershed and extract the SWAT model input files. The DEM was used to delineate the catchment and provide topographic parameters such as overland slope and slope length for each subbasin. The catchment area of the Upper Blue Nile was delineated and discretized into 15 subbasins using a 90 m DEM (http: //srtm.csi.cgiar.org).

The landuse map of the Global Land Cover Characterization (GLCC) was used to estimate vegetation and their parameters input to the model. The GLCC is part of the United States Geological Survey (USGS) database, with a spatial resolution of $1 \mathrm{~km}$ and 24 classes of landuse representation (http://edcsns17.cr.usgs.gov/glcc/glcc.html). The parameterization of the landuse classes (e.g. leaf area index, maximum stomatal conductance, maximum root depth, optimal and minimum temperature for plant growth) is based on the available SWAT landuse classes. Table 2 shows the land use and land cover types and their area coverage in the Upper Blue Nile. The land cover classes derived are Residential area $0.2 \%$, Dryland Cropland 17\%, Cropland 5.8\%, Grassland $2.5 \%$, Shrubland $1.1 \%$, Savanna $68.8 \%$, Deciduous Forest $0.02 \%$, Evergreen Forest $1.6 \%$, Mixed Forest $0.7 \%$, Water Body $2.2 \%$, and Barren $0.4 \%$.

The soil types of the study area were extracted from the SOIL-FAO database, Food and Agriculture Organization of the United Nations (FAO, 1995). There are around 23 soil 
types, with a spatial resolution of $10 \mathrm{~km}$ with soil properties for two layers $(0-30 \mathrm{~cm}$ and $30-100 \mathrm{~cm}$ depth). The soil properties (e.g. particle-size distribution, bulk density, organic carbon content, available water capacity, and saturated hydraulic conductivity) were obtained from Batjes (2002).

The USGS landuse, the FAO soil and the slope class maps were overlaid to derive 1747 unique HRUs. Although the SWAT model provides an option to reduce the number of HRUs to decrease the computation time required for the simulation, we considered all of the HRUs to evaluate the watershed management intervention impact.

Daily precipitation and minimum and maximum temperature data at 17 stations interpolated spatially over the basin were used to run the model. Most of the stations were either established recently or had a lot of missing data. Therefore, a weather generator based on monthly statistics was used to fill in the gaps. Solar radiation and wind speed were generated by the weather generator.

Daily river flow and sediment concentration data measured at El Diem gauging station (see Fig. 1) were used for the model calibration and validation. Although we know that calibrating the model at the subbasin outlets would improve the model parameterization, we could not perform it due to lack of data. The flow observations are available throughout the year, while the sediment concentrations are usually monitored during the main rainy season, which is between June and October. The Blue Nile water is relatively sediment free during the remaining months.

The model was run daily for 12 years; the period from 1990 to 1996 was used for the calibration and the period from 1998 to 2003 was used for the validation. The modelling period selection considered data availability and avoided rapid landuse/cover change that was documented as alarming until the late 1980's by Zeleke et al. (2000) and Zeleke and Hurni (2001). Sensitivity analysis was carried out to identify the most sensitive parameters for the model calibration using One-factor-At-a-Time (LH-OAT), which is an automatic sensitivity analysis tool implemented in SWAT (van Griensven et al., 2006). Those sensitive parameters were automatically calibrated using the Sequential Uncertainty Fitting (SUFI-2) algorithm (Abbaspour et al., 2004; Abbaspour et al., 2007).

\subsection{Model performance evaluation}

Model evaluation is an essential measure to verify the robustness of the model. In this study, three model evaluation methods were used following Moriasi et al. (2007) model evaluation guideline. These methods are (i) Nash-Sutcliffe efficiency (NSE), (ii) percent bias (PBIAS), and (iii) ratio of the root mean square error to the standard deviation of measured data (RSR). The Nash-Sutcliffe efficiency (NSE) is computed as the ratio of residual variance to measured data variances (Nash and Sutcliffe, 1970). The Nash-Sutcliffe is calculated using Eq. (1):

$$
\mathrm{NSE}=1-\left[\frac{\sum_{i=1}^{n}\left(X_{i}^{\mathrm{obs}}-X_{i}^{\mathrm{sim}}\right)^{2}}{\sum_{i=1}^{n}\left(X_{i}^{\mathrm{obs}}-X^{\mathrm{mean}}\right)^{2}}\right]
$$

Where:

- $X_{i}^{\text {obs }}=$ observed variable (flow in $\mathrm{m}^{3} \mathrm{~s}^{-1}$ or sediment concentration in $\mathrm{mg}^{-1}$ ).

- $X_{i}^{\text {sim }}=$ simulated variable (flow in $\mathrm{m}^{3} \mathrm{~s}^{-1}$ or sediment concentration in $\mathrm{mg} \mathrm{l}^{-1}$ ).

$-X^{\text {mean }}=$ mean of $n$ values.

$-n=$ number of observations.

The Percent bias (PBIAS) measures the average tendency of the simulated data to be larger or smaller than their observed counterparts (Gupta et al., 1999). The PBIAS is calculated with Eq. (2):

PBIAS $=\left[\frac{\sum_{i=1}^{n}\left(X_{i}^{\mathrm{obs}}-X_{i}^{\mathrm{sim}}\right) \times 100}{\sum_{i=1}^{n}\left(X_{i}^{\mathrm{obs}}\right)}\right]$

The ratio of root mean square error to the standard deviation of measured data (RSR) is calculated as the ratio of the Root Mean Square Error (RMSE) and standard deviation of the observed data (Moriasi et al., 2007), as shown in Eq. (3):

$$
\mathrm{RSR}=\frac{\mathrm{RMSE}^{\mathrm{STDEV}} \mathrm{\text {obs }}}{\mathrm{ST}}=\left[\frac{\sqrt{\sum_{i=1}^{n}\left(X_{i}^{\mathrm{obs}}-X_{i}^{\mathrm{sim}}\right)^{2}}}{\sqrt{\sum_{i=1}^{n}\left(X_{i}^{\mathrm{obs}}-X^{\text {mean }}\right)^{2}}}\right]
$$

According to Moriasi et al. (2007) model simulation judged as satisfactory if NSE $>0.5, \quad \mathrm{RSR} \leq 0.70$ and PBIAS $= \pm 25 \%$ for flow and NSE $>0.5$, RSR $\leq 0.70$ and PBIAS $= \pm 55 \%$ for sediment.

\subsection{Catchment management intervention scenarios}

Catchment management intervention involves introducing best management practices (BMPs) to reduce soil erosion and sediment transport. The SWAT model was applied to simulate the impact of BMPs on sediment reduction in the U.S. (Vache et al., 2002; Santhi et al., 2005; Bracmort et al., 2006). These BMPs were represented in the SWAT model by modifying SWAT parameters to reflect the effect the practice has on the processes simulated within SWAT (Bracmort et al., 2006). However, selection of BMPs and their parameters values is site specific and should reflect the study area reality. For this study, we selected appropriate BMPs and their 
Table 3. Scenarios description and SWAT parameters used to represent BMPs.

\begin{tabular}{|c|c|c|c|c|c|}
\hline \multirow[t]{2}{*}{ Scenarios } & \multirow[t]{2}{*}{ Description } & \multicolumn{4}{|c|}{ SWAT parameter used } \\
\hline & & \multicolumn{2}{|c|}{ Parameter name (input file) } & $\begin{array}{r}\text { Calibration } \\
\text { value }\end{array}$ & $\begin{array}{r}\text { Modified } \\
\text { value }\end{array}$ \\
\hline Scenario-0 & baseline & \multicolumn{2}{|c|}{-} & $*$ & * \\
\hline Scenario-1 & filter strip & \multicolumn{2}{|c|}{ FILTERW $(. h r u)^{* *}$} & 0 & $1(\mathrm{~m})$ \\
\hline \multirow[t]{5}{*}{ Scenario-2 } & stone bund & SLSUBBSN & $0-10 \%$ slope & $61(\mathrm{~m})$ & $10(\mathrm{~m})$ \\
\hline & & (.hru) & 10-20\% slope & $24(\mathrm{~m})$ & $10(\mathrm{~m})$ \\
\hline & & & $>20 \%$ slope & $9.1 \mathrm{~m}$ & $9.1(\mathrm{~m})$ \\
\hline & & \multicolumn{2}{|l|}{ CN2 (.mgt) } & 81 & 59 \\
\hline & & \multicolumn{2}{|c|}{ USLE_P (.mgt) } & 0.53 & 0.32 \\
\hline Scenario-3 & reforestation & \multicolumn{2}{|c|}{-} & * & * \\
\hline
\end{tabular}

* Assigned by SWAT model.

** The extensions, .hru and .mgt are input files, where parameter value was edited.

parameters values based on documented local research experience in the Ethiopian highlands (Hurni, 1985; Herweg and Ludi, 1999; Gebremichael et al., 2005).

The scenarios simulated and representations of BMPs in the SWAT are depicted in Table 3. In Scenario 0, the basin existing conditions is considered. In Scenario 1, filter strips were placed on all agricultural HRUs that are the combination of dryland cropland, all soil types and slope classes. The effect of the filter strip is to filter the runoff and trap the sediment in a given plot (Bracmort et al., 2006). Appropriate model parameter for representation of the effect of filter strips is width of filter strip (FILTERW). FILTERW value of $1 \mathrm{~m}$ was assigned to simulate the impact of filter strips on sediment trapping. This value was modified by editing the HRU (.hru) input table. The filter width value was assigned based on local research experience in the Ethiopian highlands (Hurni, 1985; Herweg and Ludi, 1999).

In Scenario 2, stone bunds were placed on agricultural HRUs that are the combination of dryland cropland, all soil types and slope classes. This practice has a function to reduce overland flow, sheet erosion and reduce slope length (Bracmort et al., 2006). Appropriate parameters for representing the effect of stone bunds are the Curve Number (CN2), average slope length (SLSUBBSN) and the USLE support practice factor (USLE_P). We modified SLSSUBSN value by editing the HRU (.hru) input table, whereas USLE_P and $\mathrm{CN} 2$ values were modified by editing Management (.mgt) input table. The SWAT model assigns the SLSUBBSN parameter value based on the slope classes. In this application, the SWAT assigned values were $61 \mathrm{~m}, 24 \mathrm{~m}$ and $9.1 \mathrm{~m}$ for slope classes $0-10 \%, 10-20 \%$ and over $20 \%$, respectively. The modified parameters values were SLSUBBSN is equal to $10 \mathrm{~m}$ for $0-10 \%$ and $10-20 \%$ slope classes, USLE_P is equal to 0.32 , and $\mathrm{CN} 2$ is equal to 59 as depicted in Table 3. The SLSUBBSN represents the spacing between successive stone bunds at field condition and the modified value was used as reported by Hurni (1985) and Herweg and
Ludi (1999). Similarly, USLE_P value was obtained from documented field experience by Gebremichael et al. (2005). The CN2 value was obtained from the SWAT user's manual version 2005 for contoured and terraced condition (Neitsch et al., 2005).

In Scenario 3, we simulated the impact of reforestation on sheet erosion. The reforestation has a function to reduce overland flow and rainfall erosivity. The reforestation effect was simulated by introducing land use change, not by parameters changes. It was deemed impractical to change agricultural land into forest completely. Thus we replaced $8 \%$ of the area occupied by cropland, shrubland, barren, mixed forest, and deciduous forest into evergreen forest. The evergreen forest was selected since it has a wider coverage than other types of forest in the study area, as shown in Table 2 . The associated parameters (e.g., plant, hydrological and erosion) for the new landuse were changed by the SWAT model from the database.

\section{Results and discussion}

\subsection{Model calibration and validation}

The most sensitive parameters for flow predictions were curve number (CN2), baseflow alpha factor (ALPHA_BF), groundwater delay time (GW_DELAY), threshold water depth in the shallow aquifer (GWQMN), ground water "revap" co-efficient (GW_REVAP), threshold water depth in the shallow aquifer for "revap" (REVAPMN), soil evaporation compensation factor (ESCO), recharge to deep aquifer (RCHRG_DP), channel effective hydraulic conductivity (CH_K2), available water capacity (SOL_AWC), saturated hydraulic conductivity (SOL_K), surface runoff lag time (SURLAG), average slope length (SLSUBBSN) and Manning's " $n$ " value for main channel (CH_N2). These flow parameters are used to calculate the amount of flow from the 

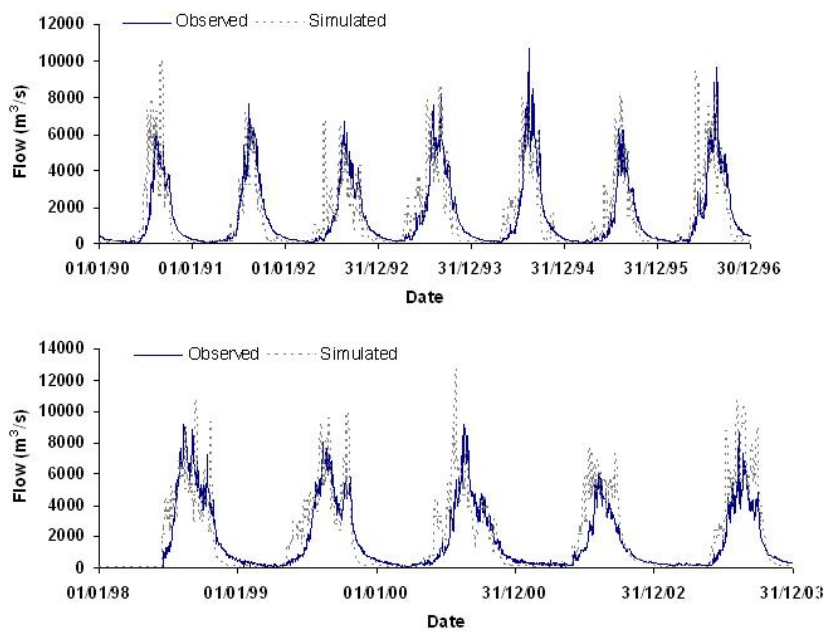

Fig. 2. Observed and simulated daily flow hydrographs at El Diem station, calibration (top) and validation (bottom).

catchment. The most sensitive parameters for erosion simulations were USLE land cover factor (USLE_C) for various land use, USLE support practice factor (USLE_P), linear re-entrainment parameter for channel sediment routing (SPCON), exponent of re-entrainment parameter for channel sediment routing (SPEXP), channel cover factor ( $\mathrm{Ch}_{-} \mathrm{COV}$ ), channel erodibility factor (Ch_Erod), and sediment routing factor in main channel (PSP). These sediment parameters are used to compute the amount of erosion from the catchment and channel. Those flow and sediment parameters were adjusted from the SWAT initial estimates to fit the model simulations with the observed flow and sediment data. These parameters and their calibrated values are displayed in Table 4.

The SWAT flow predictions were calibrated against daily flow from 1990 to 1996 and validated from 1998 to 2003 at El Diem gauging station (Ethiopia-Sudan border), as shown in Fig. 2. Note that the year 2001 is not presented in the validation period since the observed data is missing. The simulated daily flow matched the observed values for calibration period with NSE, RSR and PBIAS equal to 0.68 , 0.57 , and $10 \%$, respectively. For the validation period, the simulated and the observed daily flows showed acceptable agreement as indicated by NES, RSR and PBIAS equal to $0.63,0.61$ and $-8 \%$, respectively. The aggregated monthly average flow values from daily flow values improved the fit between model predictions and observed flows. This fit is shown by NES $=0.82, \mathrm{RSR}=0.42$ and PBIAS $=10 \%$ for the calibration and NES $=0.79, \mathrm{RSR}=0.46$, and PBIAS $=-8 \%$ for validation periods. These model fit statistics are within ranges of literature values in the Ethiopian highlands (e.g., Easton et al., 2010) as well as in areas that show similar climatic conditions to the Ethiopian highlands (e.g., Watson et al., 2005 and Cheng et al., 2006). Easton et al. (2010) reported NES $=0.53-0.92$ for daily flow calibration in the Ethiopian highlands. Whereas Watson et al. (2005) in Aus-
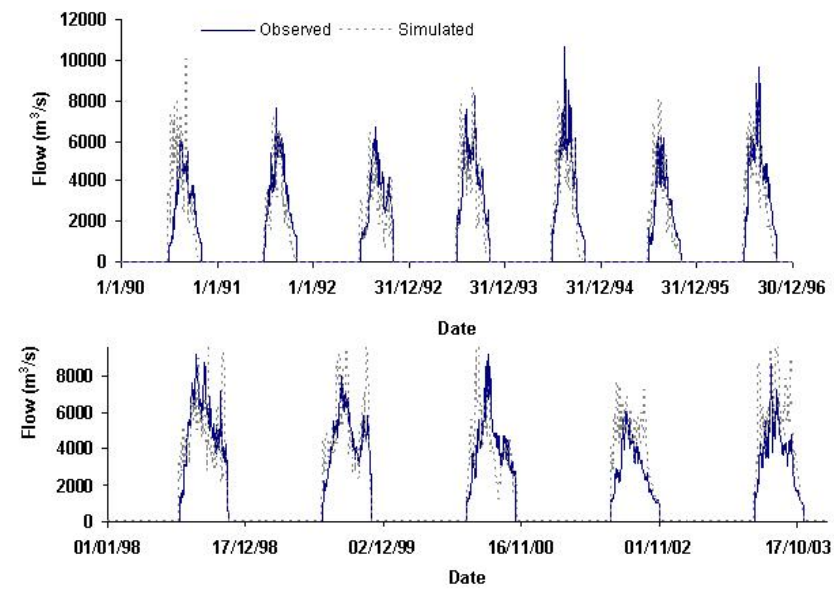

Fig. 3. Observed and simulated daily wet season (from June to October) flow hydrograph at El Diem station, calibration (top) and validation (bottom).

tralia and Cheng et al. (2006) in China reported NSE $=0.77-$ 0.78 for monthly flow calibration and NSE $=0.76-0.79$ for monthly flow validation. These results indicate that the SWAT model reasonably simulated the basin response at the Ethiopia-Sudan border using the given set of parameters.

The model slightly over predicted the flow on the rising limb and slightly under predicted the flow on the receding limb in the calibration and the validation periods (Fig. 2). There could be many reasons for the slight over and under prediction of the flow but most likely it is due to Curve Number $(\mathrm{CN} 2)$ method that is used to predict the surface runoff. The $\mathrm{CN} 2$ method assumes a unique relationship between cumulative rainfall and cumulative runoff for the same antecedent moisture condition. In the Ethiopian Highlands, however, Liu et al. (2008) showed that the ratio of discharge to effective precipitation $(\mathrm{Q} /(\mathrm{P}-\mathrm{ET}))$ is increasing with cumulative precipitation and consequently the watersheds behave differently depending on how much moisture is stored in the watershed, suggesting that saturation excess processes play an important role in watershed response. The simulated peak flow in August was slightly under predicted in four out of seven years during the calibration period. In the validation period, however, the model slightly over and under predicted the peak flow in four out of five years. There could be various reasons for the peak flow mismatch but it is most likely attributed to precipitation data. Steenhuis et al. (2009) also reported that a limited precipitation data is the main constraint for accurate flow modelling in the Blue Nile. However, it is interesting that the model well simulated the main rainy season flow, which is very important for sediment simulation as shown in Fig. 3. 
Table 4. SWAT sensitive parameters and fitted values.

\begin{tabular}{|c|c|c|c|}
\hline Variable & Parameter name & Description & $\begin{array}{r}\text { Fitted } \\
\text { parameter } \\
\text { value }\end{array}$ \\
\hline \multirow[t]{14}{*}{ Flow } & r_CN2.mgt* & Curve number & -0.02 \\
\hline & v_ALPHA_BF.gw** & Baseflow alpha factor & 0.29 \\
\hline & v_GW_DELAY.gw & Groundwater delay time & 215.59 \\
\hline & v_GWQMN.gw & Threshold water depth in the shallow aquifer & -596.16 \\
\hline & v_GW_REVAP.gw & Ground water revap co-efficient & -0.46 \\
\hline & v_REVAPMN.gw & Threshold water depth in the shallow aquifer for revap & 233.24 \\
\hline & v_ESCO.hru & Soil evaporation compensation factor & 0.58 \\
\hline & v_RCHRG_DP.gw & Recharge to deep aquifer & 1.07 \\
\hline & v_CH_K2.rte & Channel effective hydraulic conductivity & 4.22 \\
\hline & r_SOL_AWC.sol*** & Available water capacity & 0.54 \\
\hline & r_SOL_K.sol & Saturated hydraulic conductivity & 0.00 \\
\hline & r_SURLAG.bsn & Surface runoff lag time & 33.6 \\
\hline & r_SLSUBBSN.hru & Average slope length & 90.68 \\
\hline & v_CH_N2.rte & Manning's 'n' value for main channel & 0.16 \\
\hline \multirow[t]{11}{*}{ Sediment } & v_USLE_C $\{$ Dryland $\}$ & USLE land cover factor & 0.29 \\
\hline & v_USLE_C $\{$ Cropland $\}$ & USLE land cover factor & 0.03 \\
\hline & v_USLE_C $\{$ Savanna $\}$ & USLE land cover factor & 0.17 \\
\hline & v_USLE_C $\{$ Grassland $\}$ & USLE land cover factor & 0.35 \\
\hline & v_USLE_C $\{$ Shurbland $\}$ & USLE land cover factor & 0.36 \\
\hline & v_SPCON.bsn & Linear re-entrainment parameter for channel sediment routing & 0.01 \\
\hline & v_SPEXP.bsn & Exponent of re-entrainment parameter for channel sediment routing & 1.20 \\
\hline & r_USLE_P.mgt & USLE support practice factor & 0.53 \\
\hline & v_Ch_COV.rte & Channel cover factor & 0.71 \\
\hline & v_Ch_Erod.rte & Channel erodibility factor & 0.63 \\
\hline & v_PSP.bsn & Sediment routing factor in main channel & 0.12 \\
\hline
\end{tabular}

* The extension (e.g., .mgt) refers to the SWAT input file where the parameter occurs.

${ }^{* *}$ The qualifier $\left(\mathrm{v}_{-}\right)$refers to the substitution of a parameter by a value from the given range.

*** The qualifier $\left(\mathrm{r}_{-}\right)$refers to relative change in the parameter where the value from the SWAT database is multiplied by 1 plus a factor in the given range.

The SWAT sediment predictions were calibrated against measured data from 1990 to 1996 and validated from 1998 to 2003 at El Diem gauging station using daily sediment concentrations, as depicted in Fig. 4. However, sediment concentrations data are available only for the rainy season, which occurs from July to October. The fit between the model sediment predictions and the observed concentrations showed good agreement as indicated by acceptable values of the $\mathrm{NSE}=0.88, \mathrm{RSR}=0.35$ and $\mathrm{PBIAS}=-0.05 \%$ in the calibration period and $\mathrm{NES}=0.83, \mathrm{RSR}=0.61$ and PBIAS $=-11 \%$ in the validation period. The aggregated monthly average sediment concentrations from daily values improved the match between predictions and observed sediment concentrations. This is shown by $\mathrm{NES}=0.92$, $\mathrm{RSR}=0.29$ and PBIAS $=-0.21 \%$ for the calibration and $\mathrm{NES}=0.88, \mathrm{RSR}=0.34$, and PBIAS $=-11 \%$ for validation periods. This model performance is comparable to the recent results reported by Steenhuis et al. (2009) and Easton et al. (2010). Steenhuis et al. (2009) results showed that $\mathrm{NSE}=0.75$ for the calibration and $\mathrm{NSE}=0.69$ for the vali- dation and Easton et al. (2010) reported NSE $=0.74$ for the calibration at El Diem gauging station.

The model well simulated the sediment concentrations on the rising and the falling limbs of the sediment hydrograph in the calibration period (Fig. 4). Although the sediment peak was well captured in most of the calibration years, the model slightly under predicted the sediment peaks in 1993 and 1994. In contrast, the model over predicted the peak concentrations in the validation period except in 1998. The model well simulated the rising limb sediment concentrations in the whole validation period. The predicted sediment concentrations on the falling limb in the validation period duplicated the observation except in 2002 and 2003.

\subsection{Scenario analysis}

The assessment of the spatial variability of soil erosion is useful for catchment management planning. The soil erosion prone areas in the Upper Blue Nile basin are shown in Fig. 5. The SWAT model simulation shows that the 

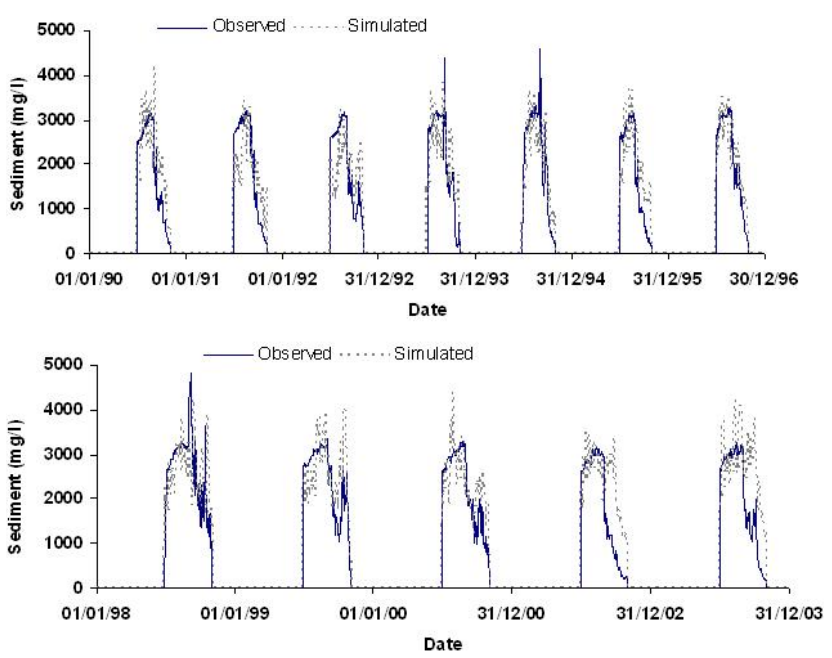

Fig. 4. Observed and simulated daily sediment concentration at El Diem gauging station, calibration (top) and validation (bottom).

soil erosion extent varies from negligible erosion to over $150 \mathrm{tha}^{-1}$. The soil erosion level in the basin classified into low (0-20 tha $\left.{ }^{-1} \mathrm{yr}^{-1}\right)$, moderate $\left(20-70 \mathrm{tha}^{-1} \mathrm{yr}^{-1}\right)$, severe $\left(70-150 \mathrm{tha}^{-1} \mathrm{yr}^{-1}\right)$ and extreme $\left(\geq 150 \mathrm{tha}^{-1} \mathrm{yr}^{-1}\right)$ categories. The low class represents the erosion extent less than the soil formation rates, which is $22 \mathrm{tha}^{-1} \mathrm{yr}^{-1}$ in the Ethiopian highlands (Hurni, 1983). The moderate class represents erosion level less than the average soil loss from cultivated land, which is $72 \mathrm{tha}^{-1} \mathrm{yr}^{-1}$ (Hurni, 1985). The extreme class represents one fold higher than the average soil loss and the severe class represents two folds higher than average soil loss. The extreme erosion was observed in the cultivated land and low erosion was observed in the savannah land. Extreme erosion was dominant in subbasins 2, 3, and 4. Severe erosion was dominant in subbasins $8,9,12,13$ and 15. Moderate erosion was dominant in subbasins 1,5 , and 6 ; and low erosion was dominant in subbasins $7,10,11$, and 14 . These results show that the erosion level variations within a subbasin and the basin that is very helpful to prioritise BMPs implementation area. Moreover, these results showed that the sediment transport to the main river decreases from the north-east to the south-west of the basin. However, emphasis should be given to relative erosion level than the absolute values because the model was not parameterized at the subbasin outlets due to lack of data.

The observed average sediment yield at the outlet of the Upper Blue Nile was $131 \times 10^{6} \mathrm{tyr}^{-1}$. The SWAT model predicted $117 \times 10^{6} \mathrm{tyr}^{-1}$ for existing conditions. This result is quite comparable with $140 \times 10^{6} \mathrm{tyr}^{-1}$ estimate by NBCBN (2005) that includes bed load as well. The bed load approximately accounts for $20-25 \%$ of the total load. However, running the model with different catchment management scenarios provided very interesting results. The simulation of filter strips scenario reduced the total sediment yield to

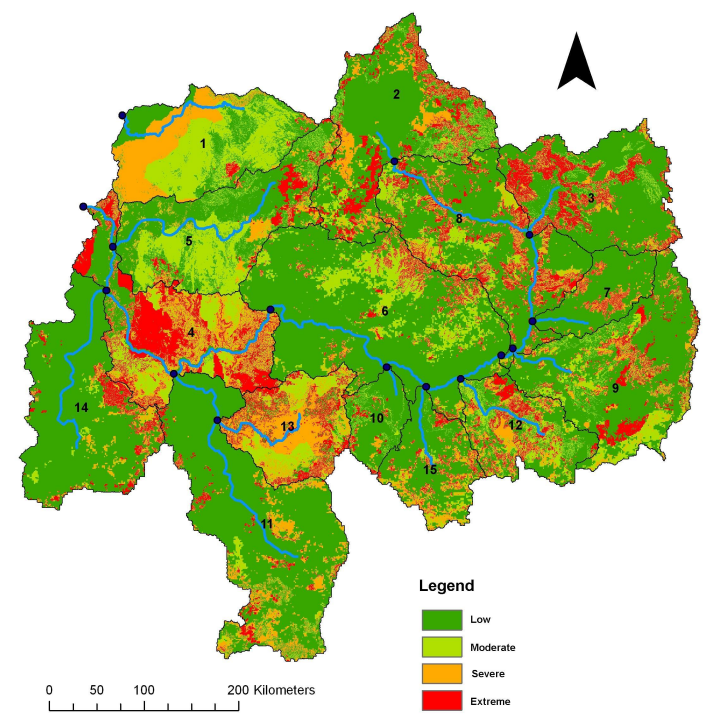

Fig. 5. Relative erosion prone areas (predicted sediment yield at each HRU by the SWAT model) for existing conditions in the Upper Blue Nile.

$66 \times 10^{6} \mathrm{tyr}^{-1}$ from current conditions at El Diem, which is equivalent to $44 \%$ reduction. The simulation of stone bunds scenario reduced the total sediment yield to $70 \times 10^{6} \mathrm{tyr}^{-1}$ from current conditions, which is equivalent to $41 \%$ reduction. The simulation of reforestation scenario showed the least reduction of sediment loads $\left(104 \times 10^{6} \mathrm{tyr}^{-1}\right)$ from current conditions at El Diem, which is $11 \%$ reduction. This less sediment reductions under reforestation scenario could be attributed to smaller implementation area compared to filter strips and stone bunds implementation area as depicted in Fig. 6. This means, the effect of reforestation scenario on sediment reductions is masked by greater sediment yields from the agricultural land. The filter strips scenario showed greater sediment reductions than stone bunds scenario for equal implementation area.

The impact of BMPs at the subbasin level showed a wider spatial variability on sediment reduction from current conditions as is shown in Fig. 7. The sediment reductions ranged from $29 \%$ to $68 \%$ under filter strips scenario, $9 \%$ to $69 \%$ under stone bunds scenario and $46 \%$ to $77 \%$ under reforestation scenario. The least reductions for filter strips scenario (29\%) and stone bunds scenario (10\% and 9\%) were exhibited in subbasins 3 and 8. Conversely, the reforestation scenario reduced sediment yields by $46 \%$ in subbasins 3 and 8 . It was observed that filter strips and stone bunds effectiveness became greater as the agricultural area decreased and the proportion of the area for slope class $\leq 20 \%$ increased. This is expected because a higher overland flow concentration occurs as the steepness and a field size increased. The reforestation effectiveness became greater as the percent of agricultural area decreased in a subbasin. This is expected because the sediment yield from agricultural area is higher, 

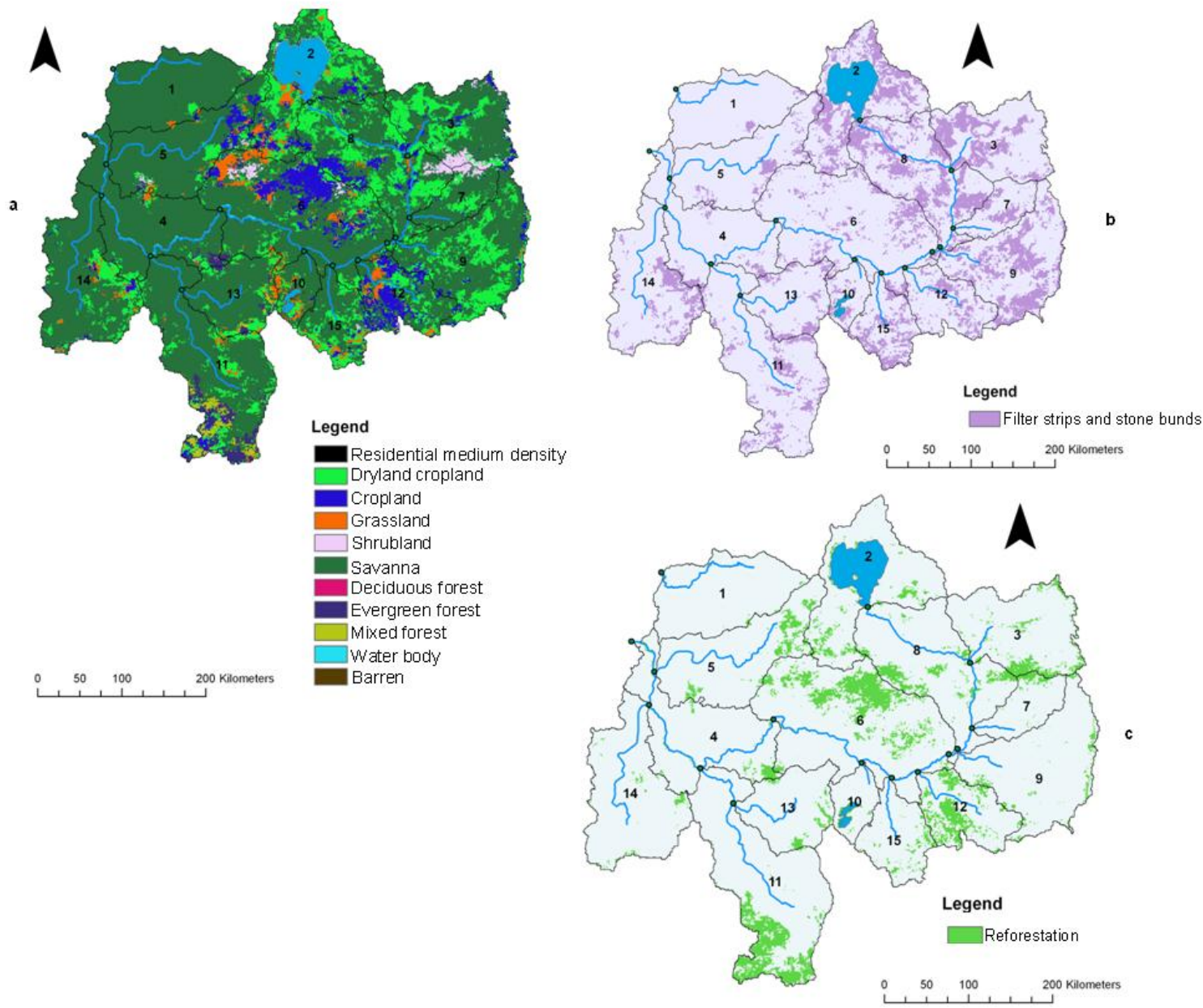

Fig. 6. Landuse (a), filter strips and stone bunds (b) and reforestation (c) maps of the Upper Blue Nile.

and subsequently, masks the effectiveness of the reforestation on sediment reduction. It is important to note that the reforestation effect is greater at the subbasin level than at the basin level. This is attributed to the reforestation implementation area at the subbasin level is greater than at the basin level. This result corroborates Santhi et al. (2005) findings that showed reductions in sediment and nutrient up to $99 \%$ at farm level and 1-2\% at the watershed level. The sediment reduction effectiveness per ha of each BMP is shown in Table 5. It shows that sediment reductions per ha of each BMP is not consistent across the entire basin. These results revealed that the BMPs became less effective as the subbasins located further from the basin outlet. Furthermore, reforestation measure was more effective than filter strips and stone bunds for the subbasins further from the basin outlet.

The BMPs sediment reductions scenarios from the model were compared to the available literature values to verify the obtained results. The filter strips sediment reductions by $44 \%$ at El Diem seems over predicted compared to Verstraeten et al. (2006). These researchers reported low (20\%) performance of filter strips at field scale due to overland flow convergence and sediment bypasses of filter strips through ditches. This is expected because filter strips become less effective as the scale increase from plot to field due to flow concentration (Dillaha et al., 1989; Verstraeten et al., 2006). The reason for the higher sediment reductions by the filter strips in this study attributed to the filter strip algorithm uses the same filtering efficiency for sediment and all nutrient forms, and it does not consider flow concentrations at the field scale (White and Arnold, 2009). To obtain a better estimate of the effectiveness of the filter strips, the improved vegetative filter strip (VFS) sub-model of SWAT2009 version should be used than the width of filter strip.

Stone bunds sediment yield reductions were quite comparable to results reported in literature (Herweg and Ludi, 1999; Gebremichael et al., 2005). Herweg and Ludi (1999) reported $72 \%-100 \%$ sediment yield reductions by stone bunds at plot scale in the Ethiopian and the Eritrean highlands. Gebremichael et al. (2005) reported $68 \%$ reductions of sediment yields by stone bunds at the field scale in the northern part of Ethiopia. It is worth noting that the scaling effect between a plot and a field is minimal even at field observation. The 
Table 5. Sediment reductions effectiveness per ha of BMPs.

\begin{tabular}{rrrr}
\hline $\begin{array}{r}\text { Sub- } \\
\text { basin }\end{array}$ & $\begin{array}{r}\text { Filter strips } \\
\text { sediment } \\
\text { reductions } \\
\text { per ha }\end{array}$ & $\begin{array}{r}\text { Stone bunds } \\
\text { sediment } \\
\text { reductions } \\
\text { per ha }\end{array}$ & $\begin{array}{r}\text { Reforestation } \\
\text { sediment } \\
\text { reductions } \\
\text { per ha }\end{array}$ \\
\hline 1 & 33 & 35 & 77 \\
2 & 2 & 1 & 6 \\
3 & 1 & 0 & 4 \\
4 & 15 & 14 & 54 \\
5 & 8 & 8 & 9 \\
6 & 7 & 7 & 4 \\
7 & 2 & 3 & 9 \\
8 & 1 & 0 & 5 \\
9 & 2 & 1 & 13 \\
10 & 4 & 3 & 5 \\
11 & 4 & 4 & 4 \\
12 & 4 & 3 & 2 \\
13 & 4 & 4 & 10 \\
14 & 4 & 3 & 31 \\
15 & 2 & 1 & 7 \\
\hline
\end{tabular}

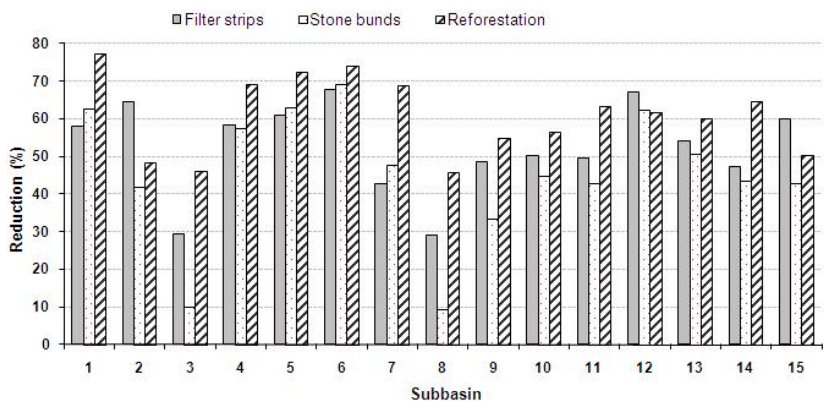

Fig. 7. Percent reductions in sediment yield due to BMPs at subbasins level of the Upper Blue Nile basin (the basin outlet is located in the subbasin 4).

reforestation sediment yield reductions well agrees with Descheemaeker et al. (2006) that reported the complete sediment yield reductions by reforestation of degraded land in northern Ethiopia. The higher sediment yield reductions observed by Descheemaeker et al. (2006) was due to the reforestation area were located down-slope from cultivated land.

\section{Conclusions}

The SWAT model was applied to model spatially distributed soil erosion/sedimentation processes at daily time step and to assess the impact of three Best Management Practices (BMPs) scenarios on sediment reductions in the Upper Blue Nile River basin. The model showed that the erosion prone area at Hydrological Response Units (HRUs) level, which is already useful information for catchment management planning. For existing conditions scenario, a reasonable agreement was obtained between the model sediment yields predictions and measured sediment yields at the basin outlet. The simulation results showed that applying filter strips, stone bunds and reforestation scenarios reduced the current sediment yields both at the subbasins and the basin outlets. The effectiveness of each BMP, however, depends upon the percentage of land available, and local topographical conditions in the basin. The potential effect of the BMPs could be obtained by implementing reforestation in steep areas, and filter strips and stone bunds in low slope areas of the catchment. These results indicate that applying BMPs could be effective in reducing sediment transport for sustainable water resources management in the basin. However, any implementation of catchment management measures to reduce sediment yields involves the use of resources and willingness of decision makers. This study shows that modelling approach could be helpful for decision makers to evaluate the cost and benefits of particular BMP measures. A definitive interpretation of the quantitative results may not be appropriate because some processes are not well represented in the SWAT model (e.g., deterioration of the BMPs, flow concentrations in filter strip and gully erosion) and lack of model parameterization at local scale (e.g., subbasin or HRU level). While this study was able to give relative estimates of the erosion measures, further model parameterization at a local scale should be done as more data and information become available.

Acknowledgements. The authors thank the EnviroGRIDS@BlackSea project under FP7 call FP7-ENV-2008-1, grant agreement No. 226740 for financial support of this research.

Edited by: T. Steenhuis

\section{References}

Abbaspour, K., Johnson, C., and van Genuchten, M.: Estimating uncertain flow and transport parameters using a sequential uncertainty fitting procedure, Vadose Zone J., 3, 1340-1352, 2004.

Abbaspour, K., Yang, J., Maximov, I., Siber, R., Bogner, K., Mieleitner, J., Zobrist, J., and Srinivasan, R.: Modelling hydrology and water quality in the pre-alpine/alpine Thur watershed using SWAT, J. Hydrol., 333, 413-430, 2007.

Ahmed, A. A.: Sediment transport and watershed management component, Friend/Nile Project, Khartoum, 2004.

Arnold, J. G., Srinivasan, R., Muttiah, R. S., and Williams, J. R.: Large area hydrologic modeling and assessment part I: model development J. Am. Water Resour. As., 34, 73-89, 1998.

Arnold, J. G., Williams, J. R., and Maidment, D. R.: Continuoustime water and sediment-routing model for large basins, J. Hydraul. Eng-ASCE, 121, 171-183, 1995.

Batjes, N.: Revised soil parameter estimates for the soil types of the world, Soil Use Manage., 18, 232-235, 2002.

BCEOM: Abay River Basin integrated master plan, main report, Ministry of Water Resources, Addis Ababa, 1999. 
Borah, D. K. and Bera, M.: Watershed-scale hydrologic and nonpoint-source pollution models: Review of mathematical bases, T. ASAE, 46, 1553-1566, 2003.

Bracmort, K., Arabi, M., Frankenberger, J., Engel, B., and Arnold, J.: Modeling long-term water quality impact of structural BMPs, T. ASABE, 49, 367-374, 2006.

Cheng, H., Ouyang, W., Hao, F., Ren, X., and Yang, S.: The nonpoint-source pollution in livestock-breeding areas of the Heihe River basin in Yellow River, Stoch. Environ. Res. Risk Assess., 21(3), 213-221, 2006.

Chow, V. T.: Open channel hydraulics, McGraw-Hill Book Company, New York, 1959.

Descheemaeker, K., Nyssen, J., Rossi, J., Poesen, J., Haile, M., Raes, D., Muys, B., Moeyersons, J., and Deckers, S.: Sediment deposition and pedogenesis in exclosures in the Tigray Highlands, Ethiopia, GEODERMA, 132, 291-314, 2006.

Dillaha, T., Reneau, R., Mostaghimi, S., and Lee, D.: Vegetative filter strips for agricultural nonpoint source pollution control, T. ASAE, 32, 513-519, 1989.

Easton, Z. M., Fuka, D. R., White, E. D., Collick, A. S., Biruk Ashagre, B., McCartney, M., Awulachew, S. B., Ahmed, A. A., and Steenhuis, T. S.: A multi basin SWAT model analysis of runoff and sedimentation in the Blue Nile, Ethiopia, Hydrol. Earth Syst. Sci., 14, 1827-1841, doi:10.5194/hess-14-1827-2010, 2010.

El-Swaify, S. and Hurni, H.: Transboundary effects of soil erosion and conservation in the Nile basin, Land Husbandry, 1, 6-21, 1996.

FAO: The Ethiopian highlands reclamation study (EHRS), Food and Agriculture Organization of the United Nations, Rome, 1986.

FAO: Digital Soil Map of the World and Derived Soil Properties, Food and Agriculture Organization of the United Nations, Rome, 1995.

Gebremichael, D., Nyssen, J., Poesen, J., Deckers, J., Haile, M., Govers, G., and Moeyersons, J.: Effectiveness of stone bunds in controlling soil erosion on cropland in the Tigray highlands, Northern Ethiopia, Soil Use. Manage., 21, 287-297, 2005.

Global Land Cover Characterization (GLCC): http://edcsns17.cr. usgs.gov/glcc/glcc.html, last access: 20 September 2007.

Green, W. H. and Ampt, C. A.: Studies on soil physics: I. Flow of air and water through soils, J. Agr. Sci., 4, 1-24, 1911.

Gupta, H., Sorooshian, S., and Yapo, P.: Status of automatic calibration for hydrologic models: Comparison with multilevel expert calibration, J. Hydrol. Eng., 4, 135-143, 1999.

Haregeweyn, N. and Yohannes, F.: Testing and evaluation of the agricultural non-point source pollution model (AGNPS) on Augucho catchment, western Hararghe, Ethiopia, Agr. Ecosyst. Environ., 99, 201-212, 2003.

Hargreaves, G., Hargreaves, G., and Riley, J.: Agricultural benefits for Senegal River basin, J. Irrig. Drain. E-ASCE, 111, 113-124, 1985.

Hengsdijk, H., Meijerink, G., and Mosugu, M.: Modeling the effect of three soil and water conservation practices in Tigray, Ethiopia, Agr. Ecosyst. Environ., 105, 29-40, 2005.

Herweg, K. and Ludi, E.: The performance of selected soil and water conservation measures-case studies from Ethiopia and Eritrea, Catena, 36, 99-114, 1999.

Hurni, H.: Soil erosion and soil formation in agricultural ecosystems: Ethiopia and Northern Thailand, Mt. Res. Dev., 3, 131$142,1983$.
Hurni, H.: Erosion - productivity - conservation systems in Ethiopia, in: Proceedings of the 4th International Conference on Soil Conservation, Maracay, Venezuela, 654-674, 1985.

Hurni, H.: Land degradation, famine, and land resource scenarios in Ethiopia, in: World Soil Erosion and Conservation, edited by: Pimentel, D., Cambridge University Press, Cambridge, UK, 2761, 1993.

Hole-filled SRTM for the globe Version 4: http://srtm.csi.cgiar.org, last access: 10 December 2009, 2008.

Liu, B. M., Collick, A. S., Zeleke, G., Adgo, E., Easton, Z. M., and Steenhuis, T. S.: Rainfall-discharge relationships for a monsoonal climate in the Ethiopian highlands, Hydrol. Process., 22, 1059-1067, 2008.

Merritt, W. S., Letcher, R. A., and Jakeman, A. J.: A review of erosion and sediment transport models, Environ. Modell. Softw., 18, 761-799, 2003.

Mohammed, H., Yohannes, F., and Zeleke, G.: Validation of agricultural non-point source (AGNPS) pollution model in Kori watershed, South Wollo, Ethiopia, Int. J. Appl. Earth. Obs., 6, 97109, 2004.

Monteith, J. L.: Evaporation and environment, Symp. Soc. Exp. Biol., 19 205-234, 1965.

Moriasi, D. N., Arnold, J. G., Van Liew, M. W., Bingner, R. L., Harmel, R. D., and Veith, T. L.: Model evaluation guidelines for systematic quantification of accuracy in watershed simulations, T. ASABE, 50, 885-900, 2007.

Nash, J. E. and Sutcliffe, J. V.: River flow forecasting through conceptual models part I-A discussion of principles, J. Hydrol., 10, 282-290, 1970.

NBCBN: Survey of literature and data inventory in watershed erosion and sediment transport, Nile Basin Capacity Building Network, Cairo, 2005.

Neitsch, S. L., Arnold, J. G., Kiniry, J., and Williams, J. R.: Soil and water assessment tool theoretical documentation (Version 2005), USDA Agricultural Research Service and Texas A\&M Blackland Research Center, Temple, Texas, 2005.

Nyssen, J., Haregeweyn , N., Descheemaeker, K., Gebremichael, D., Vancampenhout, K., Poesen, J., Haile, M., Moeyersons, J., Buytaert, W., Naudts, J., Deckers, J., and Govers, G.: Modelling the effect of soil and water conservation practices in Tigray, Ethiopia (Agric. Ecosyst. Environ. 105 (2005) 29-40), Agric. Ecosyst. Environ., 114, 407-411, 2005.

Priestley, C. and Taylor, R.: On the assessment of surface heat flux and evaporation using large-scale parameters, Mon. Weather Rev., 100, 81-92, 1972.

Santhi, C., Srinivasan, R., Arnold, J., and Williams, J.: A modeling approach to evaluate the impacts of water quality management plans implemented in a watershed in Texas, Environ. Modell. Softw., 21, 1141-1157, 2005.

Setegn, S., Dargahi, B., Srinivasan, R., and Melesse, A.: Modeling of Sediment Yield From Anjeni-Gauged Watershed, Ethiopia Using SWAT Model, J. Am. Water Resour. As., 46, 514-526, doi:10.1111/j.1752-1688.2010.00431.x, 2010.

Shahin, M.: An overview of reservoir sedimentation in some African river basins, in: Proceedings of Sediment Problems: Strategies for Monitoring, Prediction and Control, Yokohama, July 1993, LAHS Publ. no. 217, 93-100, 1993.

Steenhuis, T., Collick, A., Easton, Z., Leggesse, E., Bayabil, H., White, E., Awulachew, S., Adgo, E., and Ahmed, A.: Predicting 
discharge and sediment for the Abay (Blue Nile) with a simple model, Hydrol. Process., 23, 3728-3737, 2009.

Sutcliffe, J. and Parks, Y.: The hydrology of the Nile, IAHS Special Publication no. 5, International Association of Hydrological Sciences, Wallingford, UK, 1999.

Tamene, L., Park, S., Dikau, R., and Vlek, P.: Analysis of factors determining sediment yield variability in the highlands of northern Ethiopia, Geomorphology, 76, 76-91, 2006.

US Department of Agriculture - Soil Conservation Service (USDASCS): Urban Hydrology for Small Watersheds, USDA, Washington, DC, 1986.

US Department of Agriculture - Soil Conservation Service (USDASCS): National Engineering Handbook, Section IV, Hydrology, 4-102 pp., 1972.

Vaché, K., Eilers, J., and Santelmann, M.: Water quality modeling of alternative agricultural scenarios in the us corn belt, J. Am. Water Resour. As., 38, 773-787, 2002.

Van Griensven, A., Meixner, T., Grunwald, S., Bishop, T., Diluzio, M., and Srinivasan, R.: A global sensitivity analysis tool for the parameters of multi-variable catchment models, J. Hydrol., 324, 10-23, 2006.

Verstraeten, G., Poesen, J., Gillijns, K., and Govers, G.: The use of riparian vegetated filter strips to reduce river sediment loads: an overestimated control measure?, Hydrol. Process., 20, 4259 4267, 2006.
Watson, B. M., Srikanthan, R., Selvalingam, S., and Ghafouri, M.: Evaluation of three daily rainfall generation models for SWAT, Trans. ASABE, 48(5), 1697-1711, 2005.

Williams, J.: SPNM, a model for predicting sediment, phosphorus, and nitrogen yields from agricultural basins, J. Am. Water. Resour. As., 16, 843-848, 1980.

Williams, J. and Berndt, H.: Sediment yield prediction based on watershed hydrology, T. ASAE 20, 1100-1104, 1977.

Williams, J. R.: Flood routing with variable travel time or variable storage coefficients, T. ASAE, 12, 100-103, 1969.

White, M. J. and Arnold, J. G.: Development of a simplistic vegetative filter strip model for sediment and nutrient retention at the field scale, HYDROL. PROCESS., 23, 1602-1616, 2009.

World Bank: Africa Development Indicators 2006, The International Bank for Reconstruction and Development/World Bank, Washington, DC, 2006.

Winchell, M., Srinivasan, R., Di Luzio, M., and Arnold, J. G.: ArcSWAT interface for SWAT2005 User's guide, USDA Agricultural Research Service and Texas A\&M Blackland Research Center, Temple, Texas, 2007.

Zeleke, G.: Landscape dynamics and soil erosion process modelling in the north-western Ethiopian highlands, in: African Studies Series A, Geographica Bernensia, Berne, 2000.

Zeleke, G. and Hurni, H.: Implications of land use and land cover dynamics for mountain resource degradation in the northwestern Ethiopian highlands, Mt. Res. Dev., 21, 184-191, 2001. 